\title{
PUSAT KULINER SUNDA KELAPA
}

\author{
Steven $^{1)}$, Nina Carina ${ }^{2)}$ \\ 1) Program Studi S1 Arsitektur, Fakultas Teknik, Universitas Tarumanagara, stevenlim21@outlook.com \\ 2) Program Studi S1 Arsitektur, Fakultas Teknik, Universitas Tarumanagara, nincarin@gmail.com
}

\begin{abstract}
Abstrak
Berkembangnya zaman dan pengaruh globalisasi membentuk generasi baru yang memiliki perilaku dan kebiasaan tersendiri. Dibanding dengan generasi lainnya, milenial lebih mengutamakan pengalaman baru dibandingkan kepemilikan akan sesuatu. Pengalaman baru milenial sebagian besar diisi dengan kegiatan berwisata arsitektur ataupun kuliner. Dikembangkannya budaya kuliner suatu wilayah kota dapat menarik kedatangan dan partisipasi para milenial. Meningkatnya partisipasi milenial tentunya menghidupkan suatu kawasan dan kondisi ekonomi masyarakat sekitar. Kawasan Sunda Kelapa memiliki potensi wisata kuliner yang saat ini belum dikembangkan sehingga membutuhkan suatu fasilitas memadai. Fasilitas yang memadai tentunya dapat membangkitkan wisata kuliner dari kawasan tersebut. Pusat Kuliner Sunda Kelapa merupakan salah satu jawaban atas kebutuhan kawasan yang dirancang dengan metode fenomenologi. Metode yang memperkuat berbagai rangsangan indera yang mampu memberikan efek psikologis bagi pengunjung. Efek yang ditimbulkan memberikan pengalaman komposisi, bentuk, suhu, cahaya, suara dan aspek lainnya.
\end{abstract}

Kata kunci: Fenomenologi; Globalisasi; Kuliner; Milenial; Pariwisata

\begin{abstract}
Developing era and globalization has created new generation that has a different behaviour and their own habit. Compare to another generations, milennials value experiences more than owning things. Milennials experiences are mainly filled with architectural vacations or culinary. Developing culinary culture in a city district could attract millennials arrival and participation. Increasing millennials participation could revive a district and people's economic condition. Sunda Kelapa district has the culinary tourism potential but has not been developed yet, so that it needs an adequate facility. An Adequate facility surely could revive the culinary tourism potential. Sunda Kelapa Food Stop is one of the solution of the needs that designed with phenomenology method. Method that strenghten human sensory stimulation that gives a psychological effect to visitors. Effects that created gives experiences in composition, shapes, temperature, light, sound and other aspects.
\end{abstract}

Keywords : Culinary; Globalization; Milennial; Phenomenology; Tourism

\section{PENDAhULUAN}

Zaman serba teknologi dan pengalaman milenial yang telah melalui krisis ekonomi membuat para milenial memiliki pola pikir yang berbeda dibanding generasi lain. Tidak betah dengan kegiatan ataupun ruang monoton membuat milenial stres dan membutuhkan pengalaman menyenangkan yang berbeda. Perilaku yang berbeda ini telah tercatat data bahwa milenial merupakan generasi paling stres dibanding generasi lainnya. Hal ini diperkuat dengan hasil penelitian Euromonitor Global yang menunjukkan meningkatnya pesatnya turis milenial secara global. Peningkatan turis diprediksi akan bertambah banyak dua kali lipat dalam kurun 10 tahun kedepan.

Survei yang dilakukan oleh UNWTO (World Tourism Organization) terhadap sejumlah responden milenial, 87 persen menganggap bahwa kuliner merupakan elemen yang penting 
dalam sebuah perjalanan wisata. Melewati kuliner para wisatawan akan mendapatkan pengetahuan dan pengalaman budaya yang unik dari tempat yang dikunjungi.

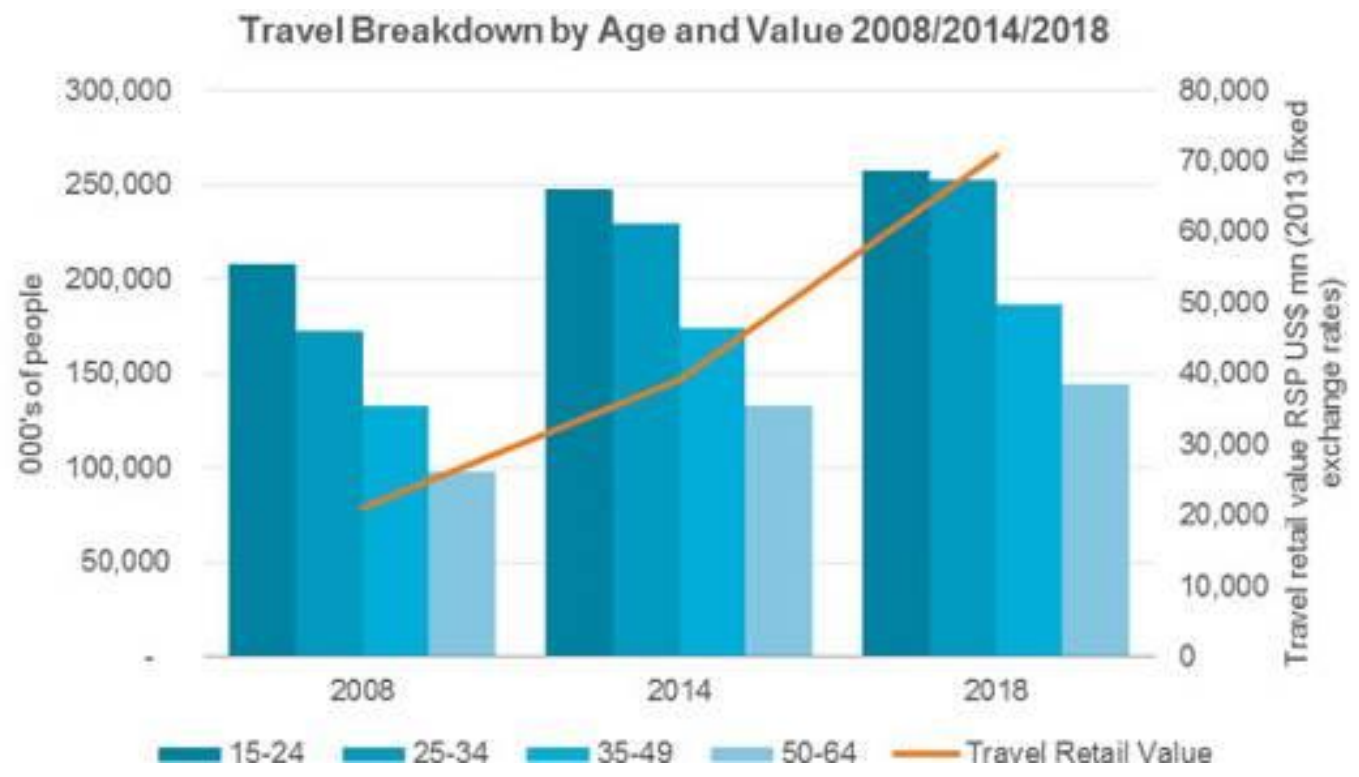

Gambar 1. Grafik Perkembangan Wisata Berdasar Usia

Sumber: Euromonitor International, 2018

Tidak hanya pakaian daerah, adat istiadat, bangunan, dan kesenian yang menjadi identitas suatu bangsa, namun juga makanan. Seseorang yang mencari pengalaman baru di suatu wilayah, arsitektur dan kuliner di daerah tersebutlah yang sangat mempengaruhi kualitas kesan dan pengalamannya. Di Jakarta terdapat berbagai kawasan dengan nilai sejarah kuat namun tidak dikembangkan secara maksimal infrastrukturnya.

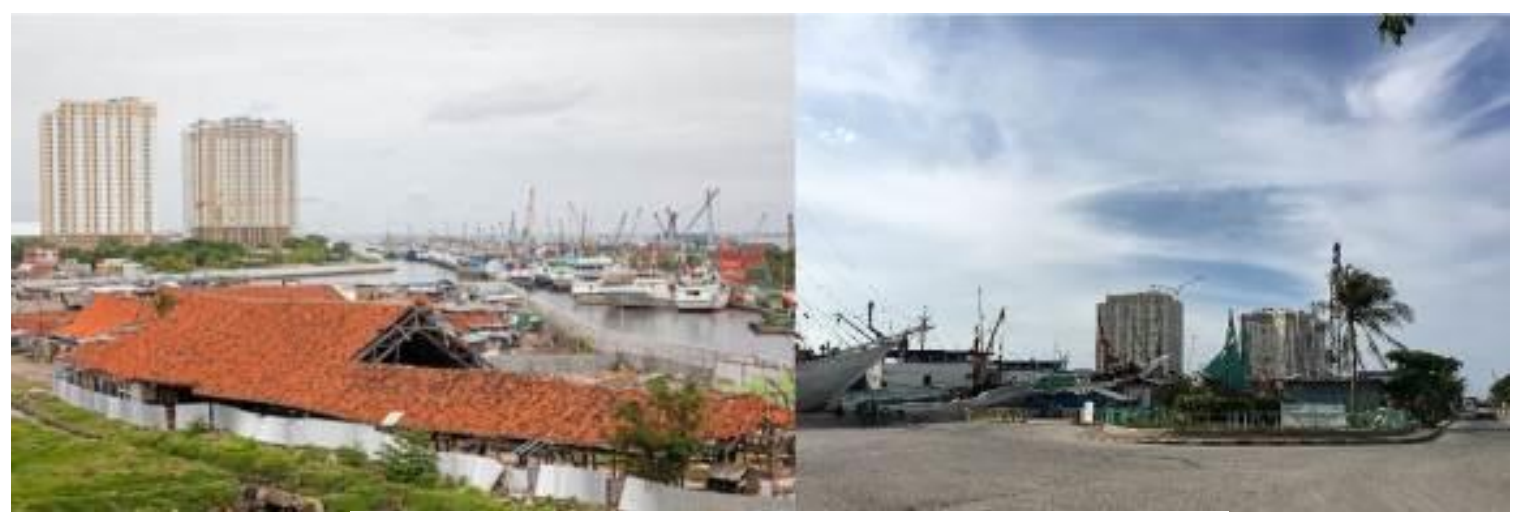

Gambar 2. Suasana Kawasan \& Pelabuhan Sunda Kelapa Sumber: Dokumen Pribadi, 2019 
Salah satu wilayah tersebut adalah Sunda Kelapa, yang banyak dikunjungi wisatawan dan memiliki berbagai jenis kuliner dari lokal, barat hingga chinese food. Namun kawasan ini tidak dilengkapi dengan sarana prasarana yang memadai. sehingga cukup menyia-nyiakan potensi wilayah yang sangat kuat. Selain itu, kualitas kawasan yang semakin lama semakin memburuk sangatlah memprihatinkan dan dapat merusak suatu peninggalan sejarah Indonesia. Usulan program Pusat Kuliner Sunda Kelapa berada pada daerah yang berarsitektur khas dan kaya akan jenis kuliner seafood. Tindakan ini tentu dapat menjawab kebutuhan milenial yang mencari pengalaman dan meningkatkan kualitas kawasan sekitarnya juga.

\section{KAJIAN LITERATUR}

\section{Karakter Milenial}

Menurut penelitian Pew Research Center, generasi milenial merupakan generasi yang lahir dari tahun 1981-1996. Teknologi memiliki peran penting dalam memisahkan antar generasi dimana generasi Baby Boomers yang dominan menonton TV, generasi $X$ melalui pengalaman revolusi komputer dan milenial bertambah dewasa seiring dengan internet menjadi bagian dari hidup sehari-hari.

\section{Millennials value experiences than things.}

Tren milenial yang paling penting adalah kurangnya minat untuk memiliki dan membeli barang melalui cara tradisional contohnya rumah. Sedangkan milenial sangat tertarik pada pengalaman indah dan tidak membeli barang seperti generasi sebelumnya. Semuanya adalah tentang mengalami gaya hidup dan pesona budaya lokal. Milenial tentunya tidak mau menderita seperti orangtuanya berdasarkan pengalaman krisis ekonomi tahun 2008 yang mempengaruhi karakter pada umumnya. Saat ini, mereka lebih memilih akses dibanding kepemilikan dan lebih menginginkan fleksibilitas.

\section{Milenial dalam Konteks Wisata}

Menurut prediksi kementrianIndonesia, wisatawan milenial akan terus tumbuh dan menjadi pasar utama. Diproyeksikan pada tahun 2030 mendatang, pasar pariwisata Asia didominasi wisatawan milenial berusia 15-34 tahun mencapai angka 57\% dimana di Indonesiajumlah milenial akan mencapai 82 juta jiwa. Generasi milenial memiliki karakter berbeda dibandingkan dengan generasi sebelumnya dimana mereka lebih rela menghabiskan uangnya untuk berekreasi dan juga berlibur ketimbang untuk berinvestasi.

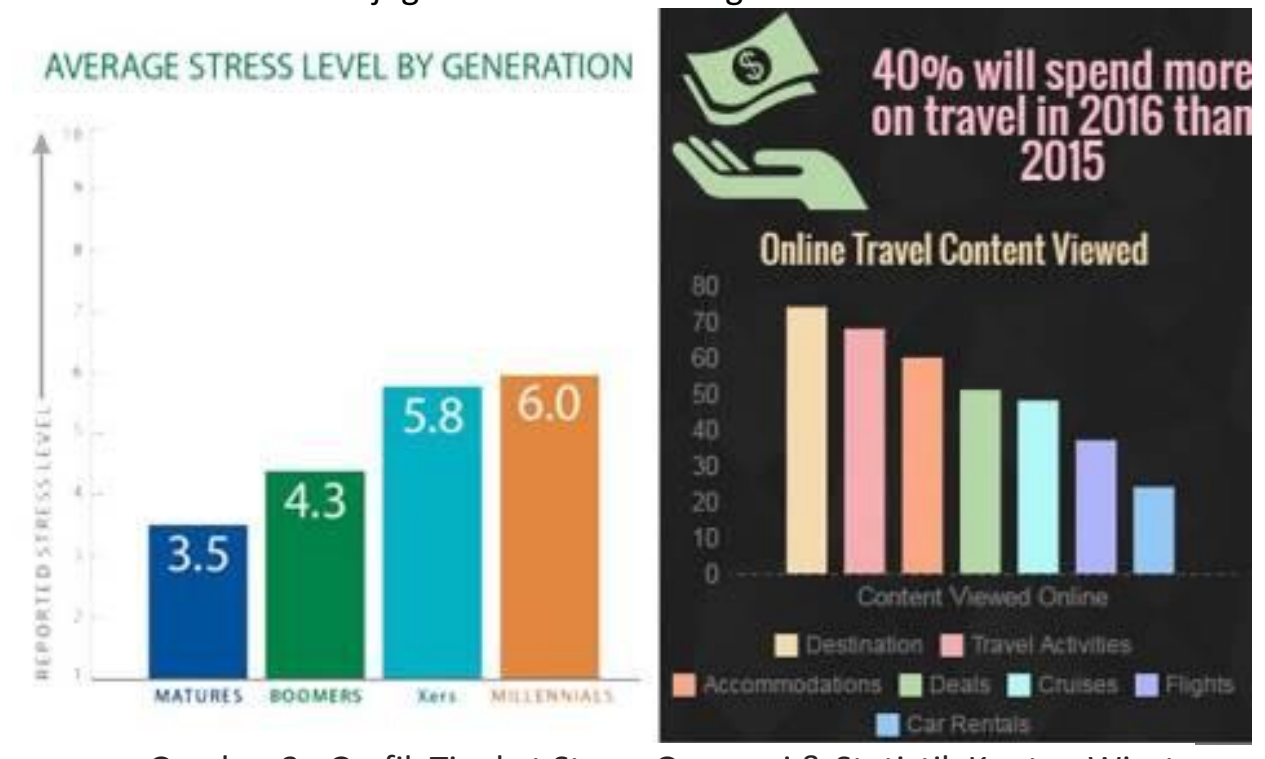

Gambar 3. Grafik Tingkat Stress Generasi \& Statistik Konten Wisata Sumber: American Psychological Association, 2016 
Angka pengeluaran konsumen di kategori rekreasi telah mengalami peningkatan sebesar 40 persen dalam tahun 2016 hingga 2018. Dari 40 persen kenaikan di kategori rekreasi, untuk kebutuhan travelling, baik dalam dan luar negeri, menunjukkan peningkatan sebesar 30 persen dalam dua tahun terakhir ini. Statistik ini menunjukkan potensi sektor wisata akan sangat menjanjikan karena jumlah konsumen yang merencanakan untuk melakukan perjalanan liburan diperkirakan akan meningkat tiga kali lipat dalam dua tahun ke depan.

\section{Milenial dalam Konteks Kuliner}

Berdasarkan riset yang dilakukan oleh Unilever Food Solutions, karakter milenial dalam berkuliner di antaranya mementingkan otentik, lokal dan bergaya modern. Mencari tempat bergaya santai nan modern dan keingintahuan yang tinggi terhadap proses makanan lebih dari rasa.

\section{Arsitektur Heritage Kawasan Sunda Kelapa}

Heritage memiliki etimologi heriter (bahasa Perancis) yang memiliki pengertian objek yang diwariskan secara turun temurun. Kumpulan bangunan-bangunan bersejarah yang membentuk suatu kompleks disebut kawasan heritage atau cagar budaya. Upaya pelestarian bangunan bersejarah disebut sebagai konservasi.

\section{METODE}

Lokasi tapak yang dipilih terletak didalam pelabuhan yang baik secara aksesbilitas, zonasi, view atau pemandangan yang dapat memperkuat fungsi komersial. Titik pemilihan tapak menghubungkan antara bangunan bersejarah dan pelabuhan. Keunikan aktivtias dan view dalam pelabuhan dilengkapi dengan jasa pelayanan wisata perahu menjadi salah satu faktor penghubung yang kuat. Desain arsitektur juga didasarkan pada konteks arsitektur sekitar kawasan yang dominan bergaya kolonial.

Pada proyek perancangan ini, diterapkan metode Infill dengan bangunan baru yang disesuaikan dengan konteks lingkungan. Suatu bangunan dikatakan infill terhadap kawasan apabila berada dalam radius $1 \mathrm{~km}$ dari bangunan cagar budaya existing. Pada metode infill, terdapat elemen visual yang perlu diperhatikan yaitu proporsi fasad, komposisi massa dan landscape. Selain itu menurut Norman Tyler terdapat empat pendekatan metode infill terlepas dari berbagai macam gaya arsitektur yaitu :

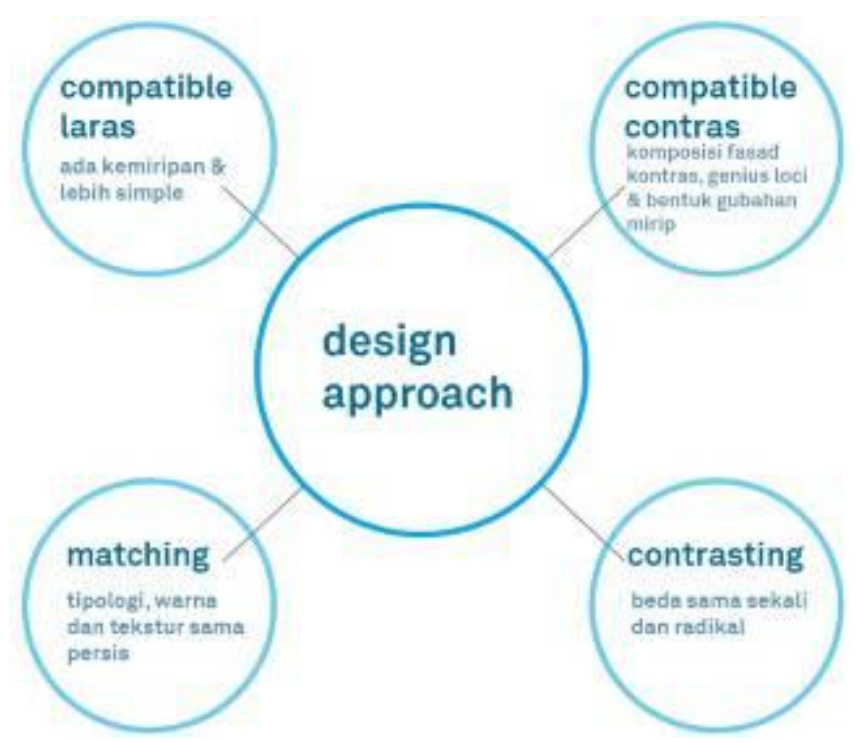

Gambar 4. Infill Design Approach

Sumber: Olahan pribadi dari buku "Historic Presevation" karangan Norman Tyler 
Perancangan difokuskan pada compatible contras yang menggunakan elemen dan hubungan fasad yang berbeda. Selain itu menggunakan material berbeda dengan bangunan sekitar namun motif serta konteks fasad yang sama.

Dalam perancangan, metode yang digunakan adalah Fenomenologi. Metode yang menitikberatkan atau menggunakan pendekatan secara kasat mata, yakni 'pengalaman sensori' terhadap setiap objek arsitektural rancangannya. Pendekatan tersebut mewujud menjadi atmosfir desainnya yang mengacu pada aspek seperti komposisi massa, indera perasa, konteks lingkungan hingga terciptanya ruang dengan cahaya.
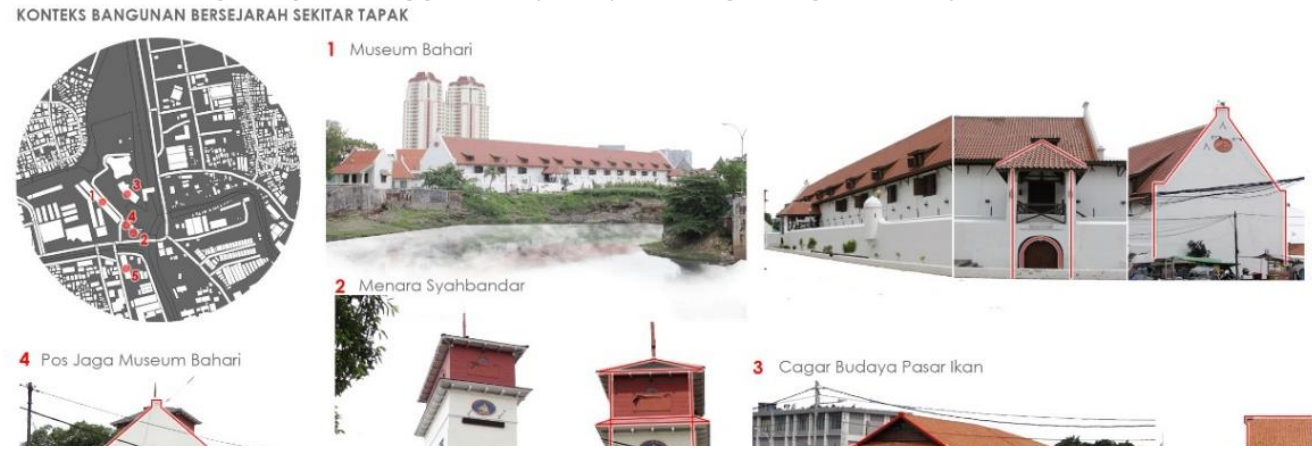

KONTEKS BANGUNAN SEKITAR TAPAK
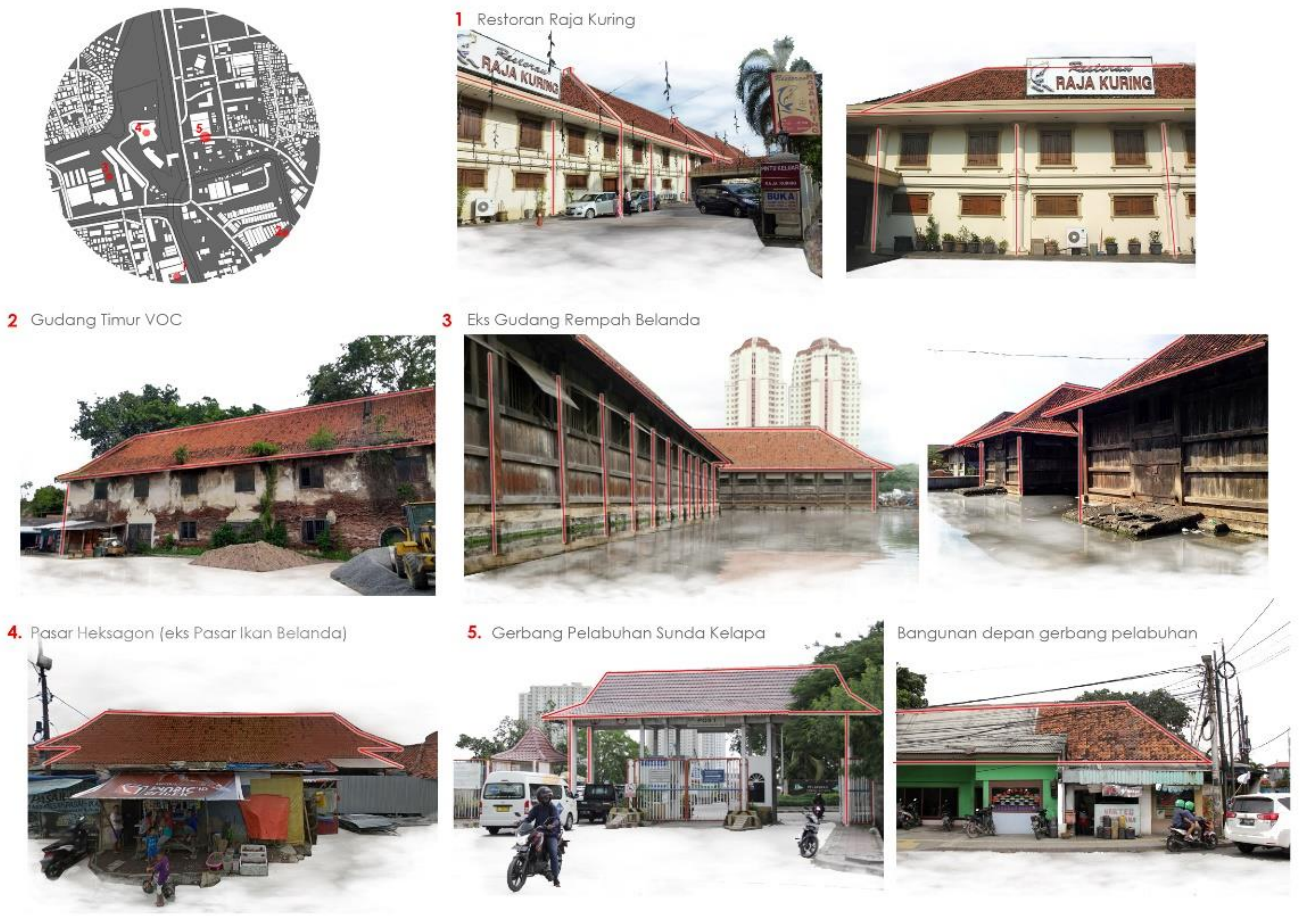

Gambar 5. Konteks Arsitektur Kawasan Sunda Kelapa Sumber: Penulis, 2019

\section{DISKUSI DAN HASIL}

Sunda Kelapa Food Stop terletak pada tapak dalam Pelabuhan Sunda Kelapa, Jakarta Utara. Tapak terletak pada zona K1 perkantoran dan memiliki luasan $2.823 \mathrm{~m}^{2}$. Program hasil perancangan berupa Food Court, Café \& Bar, Food Trucks, Cooking Studio, Culinary Gallery, Multipurpose room dan Culinary Library. Seluruh program memiliki luasan $4.831 \mathrm{~m}^{2}$. Perancangan menyesuaikan gaya bangunan dengan konteks kawasan bersejarah sekitar tapak. Perancangan dalam dan luar ruang memadukan gaya kolonial dan tipologi ruang makan tipologi milenial yang memberikan pengalaman ruang makan unik.

Perancangan ruang makan mengacu pada studi ruang dalam skala besar seperti pasar. Tipologi pasar menunjukkan berbagai jenis ruang jual membeli dalam berbagai bentuk, keterbukaan dan struktur. Kemudian dilakukan studi terhadap perilaku dan aktivitas milenial 
saat makan. Aktivitas milenial tersebutlah yang memungkinkan untuk terciptanya ruang arsitektur baru. Perpaduan antara tipologi yang sudah ada dan milenial ini memungkinkan terciptanya ruang makan yang sangat terbuka bagi semua kalangan dan dapat meningkatkan kualitas kawasan sekitar.

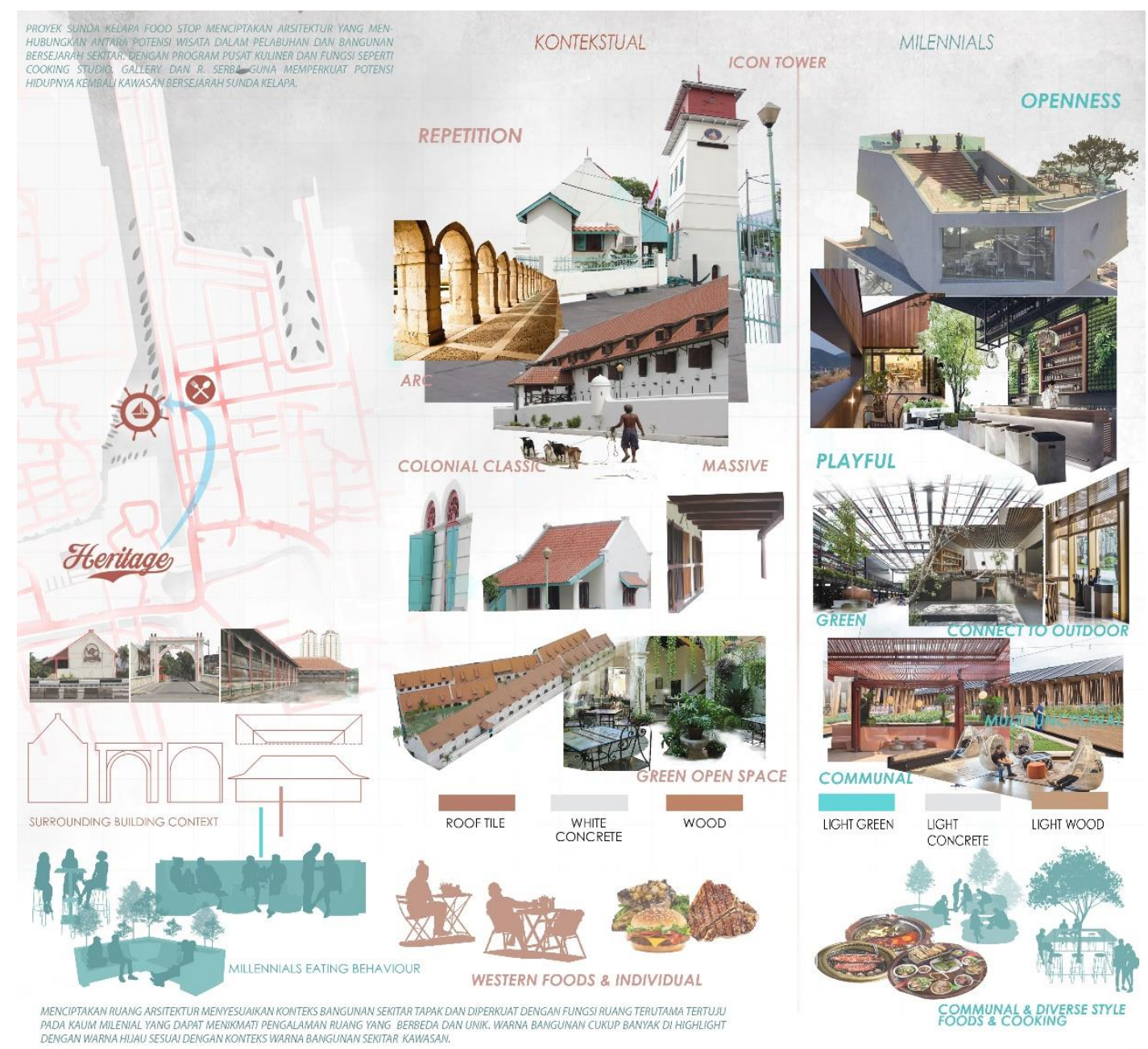

Gambar 6. Konsep Perancangan

Sumber: Penulis, 2019

Tema program kuliner perancangan disesuaikan dengan konteks kuliner sekitar kawasan yang kaya. Konteks kuliner sekitar kawasan beragam seperti seafood lokal, chinese seafood hingga western foods. Setiap lantai memiliki keunikan tema dan tipologi ruang tersendiri. Dengan penataan tempat duduk, sirkulasi dan desain ruang menciptakan suatu pengalaman ruang tersendiri bagi pengunjung terutama bagi milenial.

Fasad dan komposisi massa bangunan juga tentunya disesuaikan dengan konteks lingkungan sekitar. Penggunaan elemen arc yang bergaya kolonial, repetisi pada elemen seperti kolom dan dinding dan tema ruang yang klasik. Gaya arsitektur kolonial dipadukan dengan gaya ruang terkini yang memberi pengalaman ruang unik dalam sirkulasi ataupun komposisi ruang, terkoneksi dengan outdoor dan tentunya ruang komunal. Perpaduan gaya fasad, sirkulasi dan tema ruang antara klasik dan milenial tentunya menciptakan suatu ruang baru yang menarik bagi setiap kalangan terutama milenial. Terciptanya ruang baru di tengah kawasan Sunda Kelapa, tentunya dapat menciptakan pembaharuan hingga potensi pariwisata kawasan yang meningkat. 
JENIS TIPOLOGI PASAR
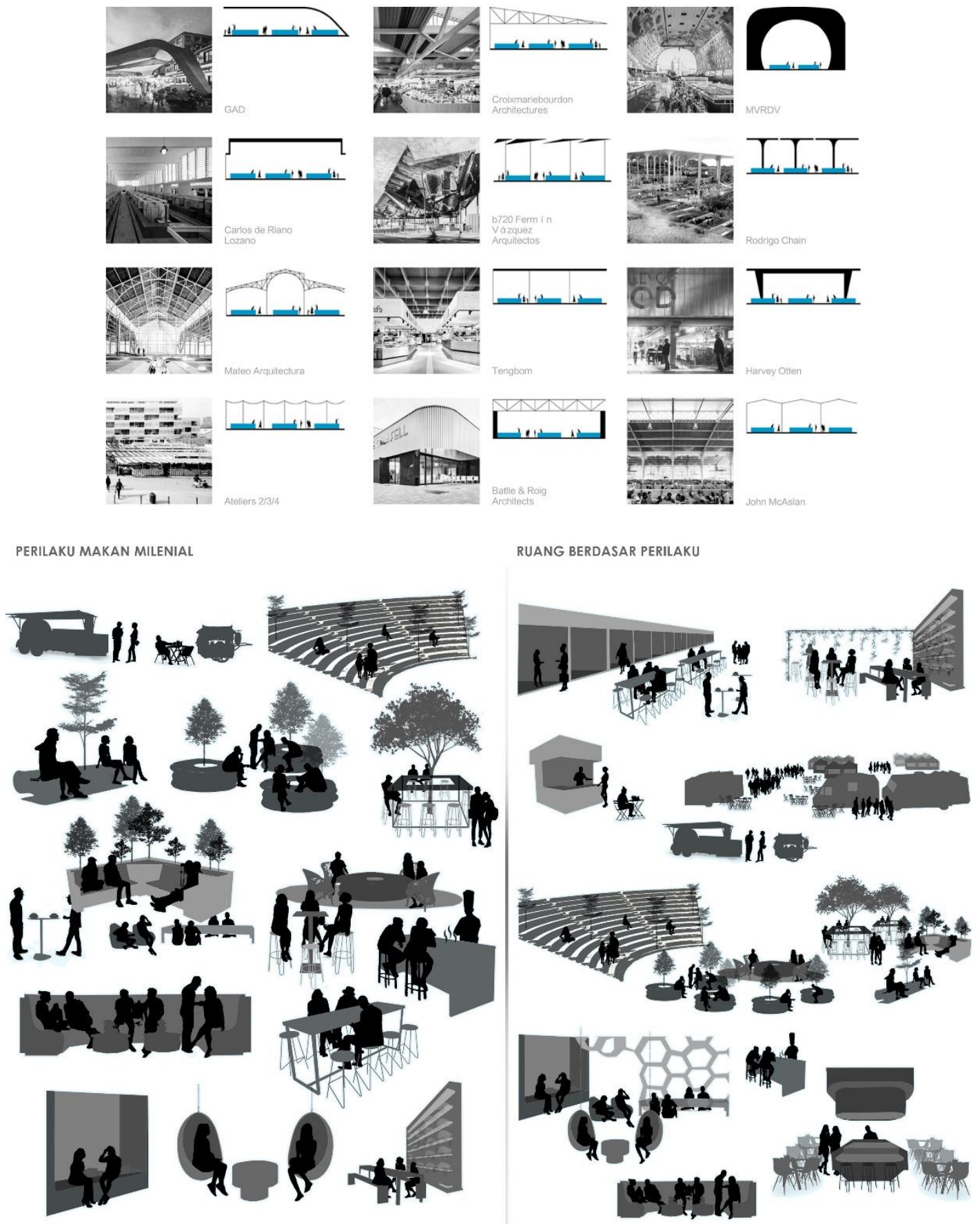

Gambar 7. Tipologi Bangunan Pasar \& Aktivitas Makan Milenial Sumber: Penulis, 2019

Berikut hasil perancangan ruang memadukan konteks sekitar kawasan dengan tipologi makan milenial. Kemudian diterapkan metode fenomenologi dalam sirkulasi, komposisi ruang, suasana dan aspek lainnya. Desain ruang mempertahankan material klasik yaitu kayu hijau (konteks kawasan), beton putih dan atap genteng. Kemudian menciptakan keterbukaan dan memadukannya dengan material arsitektur kontemporer seperti kaca dan baja. Ruang makan yang tercipta juga memungkinkan milenial untuk saling berinteraksi, mengalami keunikan pengalaman ruang dan menikmati ataupun mempelajari konteks kuliner sekitar. 

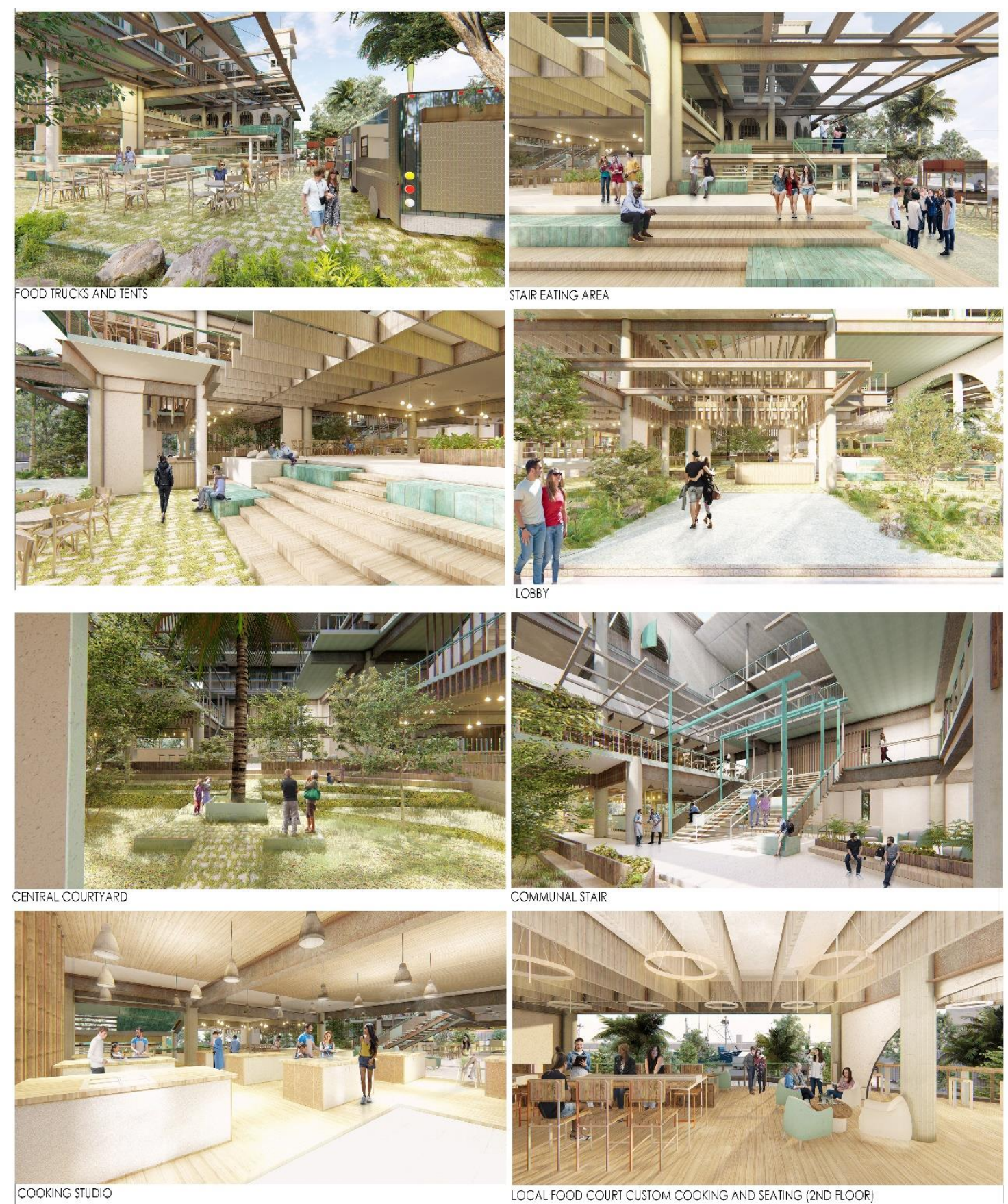

Gambar 8. Interior Bangunan Pusat Kuliner Sunda Kelapa

Sumber: Penulis, 2019 
Berikut merupakan denah dan zonasi ruang dalam bangunan:

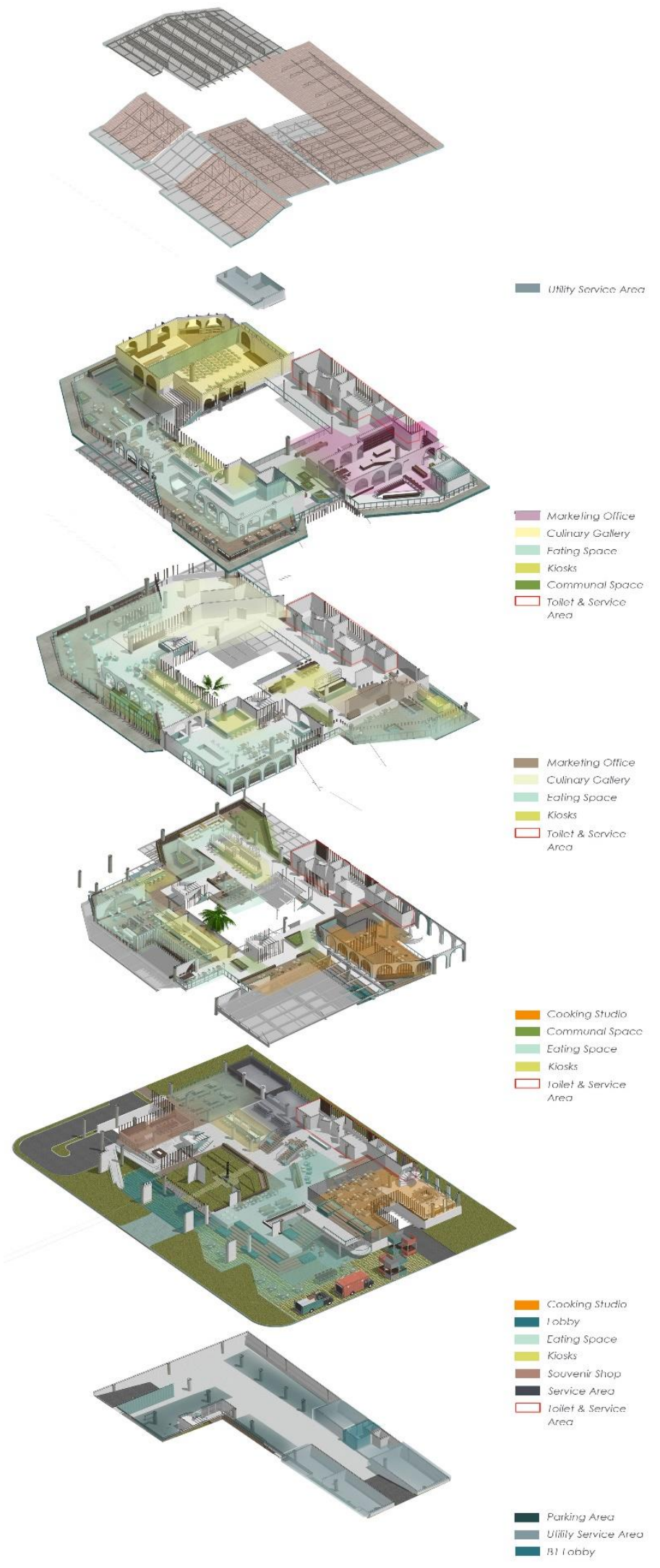

Gambar 9. Aksonometri Denah \& Zonasi Program Ruang Sumber: Penulis, 2019 


\section{KESIMPULAN DAN SARAN \\ Kesimpulan}

Disimpulkan bahwa Sunda Kelapa Food Stop berperan sebagai wadah pusat pariwisata kuliner. Terciptanya wadah wisata kuliner tidak lepas dari pertimbangan peningkatan wisatawan milenial secara global. Terutama untuk memenuhi kebutuhan milenial yang membutuhkan pengalaman unik dan sekaligus memperkuat potensi wisata Sunda Kelapa. Wisata Kuliner ini menghubungkan kembali antara berbagai bangunan bersejarah dengan pelabuhan Sunda Kelapa. Bangunan yang didesain dengan gaya kolonial sehingga menghargai konteks sekitar. Permainan ruang berdasarkan studi tipologi cara makan milenial. Pusat kuliner juga bertujuan untuk mengumpulkan berbagai jenis kuliner kawasan Sunda Kelapa yang tidak mudah diakses wisatawan. Dengan desain ini, bangunan bisa dipastikan dapat meningkatkan tingkat ekonomi sekitar, wadah bagi para milenial bekerja ataupun beraktivitas dan melestarikan konteks bangunan sekitar. Meningkatkan ekonomi sekitar terutama pelayanan wisata yang sudah ada pada sekitar kawasan. Pelayanan seperti perahu keliling dalam pelabuhan, lapangan kerja tour guide atau penjualan kuliner hingga meningkatkan kunjungan ke bangunan bersejarah di sekitar pelabuhan.

Saran

Terdapat alternatif pengembangan kawasan untuk menciptakan lebih banyak ruang terbuka bertema container sekitar, mengembangkan wisata laut yang menarik bagi para pengunjung. Kemudian dapat dikembangkan dengan meningkatkan infrastruktur yang sangat memadai dalam ataupun luar pelabuhan. Dengan infrastruktur yang baik tentunya memperkuat potensi pariwisata dan meningkatkan kualitas ekonomi serta kawasan sekitar.

\section{REFERENSI}

Attribution, C. C. (2018). Data Jumlah Penduduk Berdasarkan Kelompok Usia. Retrieved from Jakarta Open Data: http://data.jakarta.go.id/dataset/data-jumlah-penduduk-provinsi-dkijakarta-berdasarkan-kelompok-usia-per-kelurahan/resource/3c672c08-a94c-4e57-8ce967e3d357d1d0.2018, Diakses 2018, July 4

Farrington, R. (2019). What Is The Millenial Age Range And What Does That Mean Financially? Retrieved from The College Investor: https://thecollegeinvestor.com/19793/millennial-agerange/. Diakses 2019, February 13

Gronlund, J. (2018). Why Millenials Value Experiences Not Stuff. Retrieved from Business to Community: https://www.business2community.com/strategy/why-millennials-valueexperiences-not-stuff-02142266. Diakses 2018, November 21

Handa, V. (2018). A Social Space for Gastronomical Engagement in Delhi. The Food Hub.

Jormakka, K. (2008). Basic Design Methods. Birkhauser.

Litbang, B. (2018). Riset: TIngkat Stres Ubah Pola Konsumsi Generasi Milenial di Indonesia. Retrieved from Badan Litbang: http://litbang.kemendagri.go.id/website/riset-tingkat-stresubah-pola-konsumsi-generasi-milenial-di-indonesia/. Diakses 2018, May 17

Loria, K. (2015). It's official: millennials are the most stressed-out generation. Retrieved from Business Insider: https://www.businessinsider.com/millennials-are-the-most-stressed-out2015-2/?IR=T. Diakses 2015, February 6

Paramitha, T. (2018). 8 Tren Milenial dalam Industri Kuliner. Retrieved from VIVA: https://www.viva.co.id/gaya-hidup/kuliner/1025104-8-tren-milenial-dalam-industri-kuliner. Diakses 2018, April 10

Plowright, P. D. (2014). Revealing Architecture Design. Routledge.

Serafino, J. (2018). New Guidelines Redefine Birth Years for Millennials, Gen-X, and 'PostMillennials'. Retrieved from Mental Floss: http://mentalfloss.com/article/533632/newguidelines-redefine-birth-years-millennials-gen-x-and-post-millennials. Diakses 2018, March 1 
Thomas, L. (2018). Why Millennials are the Most Stressed Generation. Retrieved from Intention Inspired: https://intentioninspired.com/why-millennials-are-the-most-stressed-generation/

Wilkinson, T. (2018). The Market Typology. Retrieved from The Architectural Review: https://www.architectural-review.com/essays/typology-market-hall/10036729.article.

Diakses 2018, October 31 
